\title{
Strengthening Bauchi State College of Nursing and Midwifery by updating its training curricula, procedure manuals and student handbooks
}

Ekechi Okereke

Population Council

Ibrahim Suleiman

Population Council

Aisha Jibril

Population Council

Follow this and additional works at: https://knowledgecommons.popcouncil.org/departments_sbsr-rh

Part of the Family, Life Course, and Society Commons, International Public Health Commons, Maternal and Child Health Commons, Nursing Midwifery Commons, and the Women's Health Commons How does access to this work benefit you? Let us know!

\section{Recommended Citation}

Okereke, Ekechi, Ibrahim Suleiman, and Aisha Jibril. 2019. "Strengthening Bauchi State College of Nursing and Midwifery by updating its training curricula, procedure manuals and student handbooks," project brief. Abuja: Population Council. 


\section{STRENGTHENING BAUCHI STATE COLLEGE OF NURSING AND MIDWIFERY BY UPDATING ITS TRAINING CURRICULA, PROCEDURE MANUALS AND STUDENT HANDBOOKS}

\section{INTRODUCTION}

Many of Nigeria's Nursing and Midwifery schools and colleges encounter challenges that include outdated training curricula, which can lead, in some cases, to loss of accreditation.

Training health care workers is a health training institution core function ${ }^{1,2}$. Nigeria's health training institutions include colleges or schools specifically for nurse and midwife training, supervised by their respective regulatory bodies ${ }^{3}$. Nigeria's nursing and midwifery institutions are supervised by the Nursing and Midwifery Council of Nigeria (NMCN), which stipulates minimum standards of compliance for accreditation.

\section{BACKGROUND}

Bauchi state's federal university-Abubakar Tafawa Balewa University-has a College of Nursing and Midwifery, but in 2011 the state government decided to establish a state College of Nursing and Midwifery, which was formally established in 2013. Necessary infrastructure and other basic requirements were not ready for the College's NMCN accreditation, however; the Human Resources for Health (HRH) project (see box), which began in 2014, was designed to address some of the College's accreditation challenges. A preliminary assessment began in 2015, with a comprehensive assessment completed the following year. The assessment report recommended new training curricula, procedure manuals, and student handbooks that conform to international best practices, and approved by NMCN, to secure accreditation.

\section{ADAPTING AND UPDATING BAUCHI STATE COLLEGE OF NURSING AND MIDWIFERY TRAINING CURRICULUM, PROCEDURE MANUALS, AND STUDENT HANDBOOKS}

Population Council discussed its planned HRH support with both Bauchi State College of Nursing and Midwifery and NMCN. The Council engaged a curriculum expert who had worked with NMCN to assess the school's training documents, including its training curriculum, procedure manual, and student handbook. The assessment recommended a study tour to an accredited Nursing and Midwifery school in a nearby state, and a five-member assessment team-with the College's provost,
This HRH project, Enhancing the Ability of Frontline Health Workers to Improve Health in Nigeria, is a health systems-strengthening project implemented in Nigeria by the Population Council, Global Health Workforce Alliance (GHWA), and the World Health Organization (WHO).

Funded by Global Affairs Canada (GAC), the project began in 2014 in two states, Cross River and Bauchi.

The HRH project works with the federal Ministry of Health and the regulatory bodies Community Health Practitioners' Registration Board of Nigeria (CHPRBN) and NMCN, in addition to the states' pre-service health training institutions.

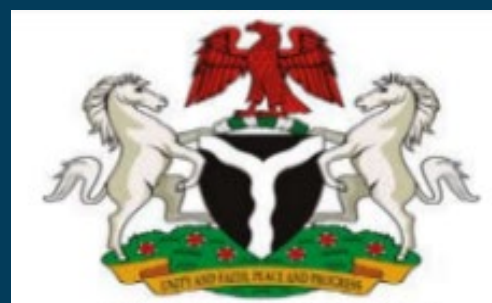

BAUCHI STATE

MINISTRY OF HEALTH 
directors of Nursing and Midwifery, and Bauchi state's Ministry of Health directors of Nursing and Planning, Research and Statistics-visited the School of Nursing and Midwifery in Zamfara state (in northwestern Nigeria), with HRH project support. An NMCN assessment team also visited Bauchi and devised recommendations for the school's accreditation.

Population Council facilitated coordination of the curriculum expert and Bauchi's NMCN Zonal Coordinator with the College's curriculum review committee, for adapting and updating its training curricula and procedure manuals. The team also adapted and updated the community midwifery curriculum. These updates incorporated international best practices along with national policies such as the task shifting and -sharing policy.

Validation meetings with curriculum review committee members, Ministry of Health and NMCN officials, curriculum experts, and Council staff finalized the documents for printing and distribution.

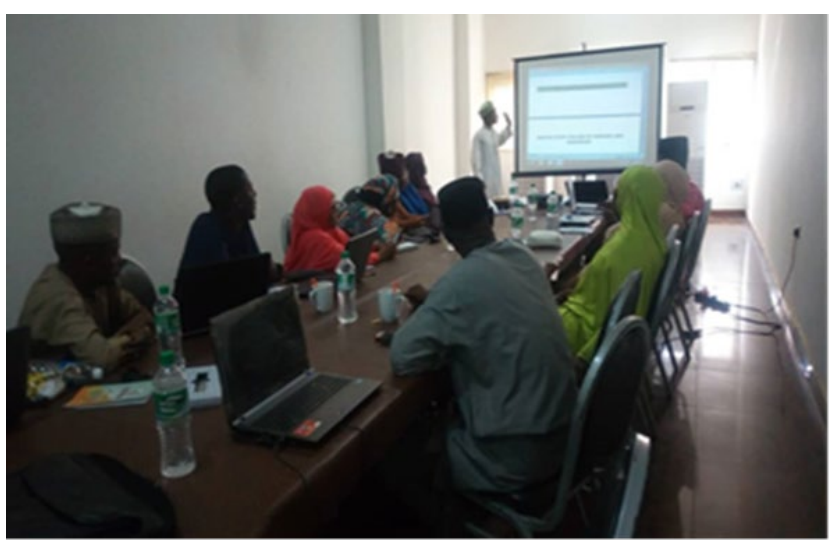

A curriculum review committee meeting

\section{SECURING ACCREDITATION AND CURRICULUM REVIEW COMMITTEE STRENGTHENING}

In 2017 the College secured provisional NMCN accreditation to enroll and train students. With continuing $\mathrm{HRH}$ project support, Bauchi State College of Nursing and Midwifery is expected to secure full accreditation in 2019.

Population Council also supported the strengthening of the curriculum review committee, which now meets regularly to discuss both tutor and student recommendations on use of the new materials.

Population Council's support for the curriculum review committee will be sustained beyond the HRH project's lifespan as a result of the project's sustained capacitybuilding and mentoring.

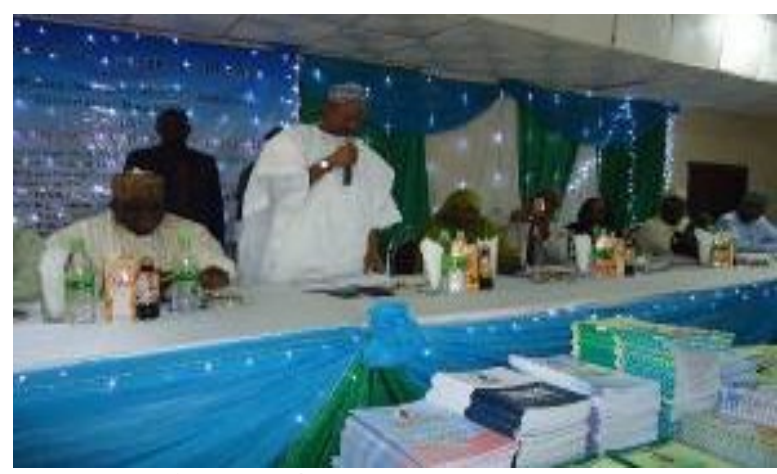

Presentation Ceremony for the updated training materials with Bauchi's Deputy Governor and Hon. Commissioner of Health

\section{CONCLUSION}

Adequate standards for the curricula, procedure manuals, and student handbooks of health training institutions are required for the effective training of key frontline healthcare providers such as nurses and midwives, to address the high maternal, newborn and child health morbidity and mortality in Nigeria. It is important that this is a collaborative process involving NMCN and the management team and curriculum review committee members of health training institutions such as colleges and schools of Nursing and Midwifery.

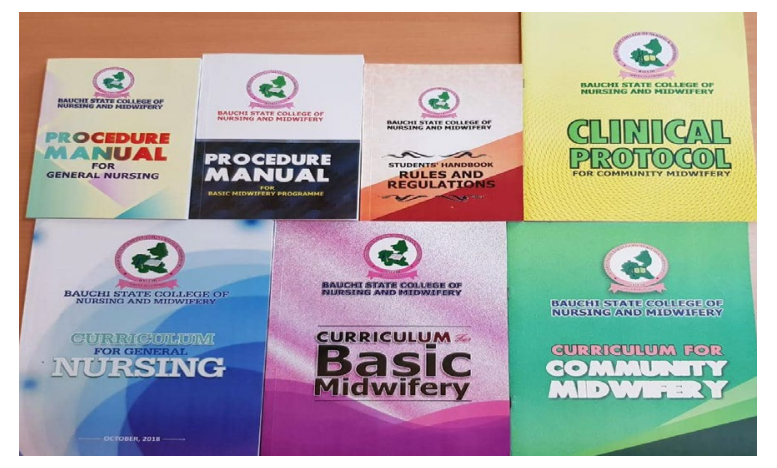

\section{CITATIONS}

1. World Health Organization. 2010. Guidelines on Quality Assurance and Accreditation of Nursing and Midwifery Educational Institutions. Geneva: WHO.

2. World Health Organization. 2013. Transforming and Scaling Up Health Professional Education and Training. Policy Brief on Regulation of Health Professional Education. Geneva: WHO.

3. Essel HB, M Boakye-Yiadom, S Mohammed. 2018. Internal Quality Assurance Practices of Nursing and Midwifery Training Colleges and the Role of Regulatory Bodies: The Perspectives of Health Tutors. Journal of Nursing Education and Practice 8(10).

\section{CONTACT US}

Ekechi Okereke HRH Project Director

Population Council Nigeria eokereke@popcouncil.org
Ibrahim Suleiman HRH Program Administrator, Bauchi

Population Council Nigeria isuleiman@popcouncil.org
Aisha Jibri

Program Officer

Population Council Nigeria

ajibril@popcouncil.org 